\title{
Laboreal
}

Volume 13 NN$^{\circ} 2$ | 2017

Varia

\section{El sistema Taylor y la fisiología del trabajo profesional}

Texto original: Lahy, J.-M. (1916). Le système Taylor el la physiologie du travail professionnel (Introduction). Paris : Masson.

O sistema Taylor e a fisiologia do trabalho profissional

Le système Taylor et la physiologie du travail professionnel

Taylor's system and the physiology of the professional work

\section{Jean-Maurice Lahy}

Traductor. Patricio Nusshold

\section{OpenEdition}

\section{Journals}

Edición electrónica

URL: http://journals.openedition.org/laboreal/355

DOI: $10.4000 /$ laboreal.355

ISSN: $1646-5237$

\section{Editor}

Universidade do Porto

\section{Referencia electrónica}

Jean-Maurice Lahy, «El sistema Taylor y la fisiología del trabajo profesional », Laboreal [En línea], Volume 13 No2 | 2017, Publicado el 01 diciembre 2017, consultado el 15 septiembre 2020. URL: http://journals.openedition.org/laboreal/355

Este documento fue generado automáticamente el 15 septiembre 2020.

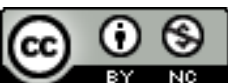

Laboreal está licenciado com uma Licença Creative Commons - Atribuição-NãoComercial 4.0 Internacional. 


\section{El sistema Taylor y la fisiología del trabajo profesional}

Texto original: Lahy, J.-M. (1916). Le système Taylor el la physiologie du travail professionnel (Introduction). Paris : Masson.

o sistema Taylor e a fisiologia do trabalho profissional

Le système Taylor et la physiologie du travail professionnel

Taylor's system and the physiology of the professional work

Jean-Maurice Lahy

Tradución : Patricio Nusshold

\section{Introducción}

1 El hombre se diferencia de los seres vivos y del ser automático, que es la máquina, por la diversidad casi ilimitada de sus imágenes mentales y gestos, y por las relaciones que establece entre su pensamiento y sus actos en vista de conducirlos a la perfección. No obstante, en cuanto el hombre se encuentra en el trabajo, sus imágenes y gestos se reducen a las necesidades de su profesión; el campo de su conciencia se achica. La tendencia moderna a limitar la actividad humana afín de obtener una adaptación precisa de los gestos, conduce a una pérdida y a una ganancia. Si, por un lado, la manufacturación de la materia prima se realiza bajo las mejores condiciones de velocidad y cantidad y el obrero alcanza a la perfección el gesto correlativo a la precisión de las imágenes mentales, por otro lado, el exceso de rigidez en el pensamiento y en los actos, reduce al individuo. Es necesario buscar entonces el punto de equilibrio entre un automatismo humano demasiado grande ligado al trabajo moderno y la dispersión del pensamiento debido a la ausencia de restricciones.

En la medida en que excede una duración óptima, la ley del rendimiento incrementado, juega en contra del desarrollo psicológico y fisiológico normal del hombre. Cuanto más éste se encuentre restringido a una labor fija, más debe gozar, por otro lado, de una 
libre iniciativa afín de encontrar la multiplicidad de imágenes y realizar, por su juego complejo, actos variados y útiles.

Cada vez que se trató de organizar el trabajo sobre bases nuevas, los organizadores han puesto en primer plano el perfeccionamiento de la técnica, considerando al obrero como un elemento de producción, un complemento a la herramienta. Respecto al contexto en el que debe ejercerse su actividad no especializada, siempre ha sido ignorado, dejando a la iniciativa individual la tarea de encontrar las medidas que preservarán al ser humano y a la raza. Es de ahí que ha nacido para los trabajadores la necesidad de agruparse, de actuar, sin el acuerdo de los organizadores del trabajo, y de oponerse a ellos en graves conflictos.

4 La obra de W. Taylor es el punto culmine de una evolución en las formas de trabajo en las que la preocupación no sólo se encuentra centrada en el rendimiento profesional. El ingeniero estadounidense simplifica los gestos y los métodos de trabajo, no en vistas del bienestar del obrero, sino afín de asegurar la sobreproducción de cada uno.

5 Esta nueva concepción del trabajo se encuentra enturbiada por un tiple error: psicológico, sociológico, industrial.

El obrero, aún si da a la fábrica la mayor parte de sus fuerzas y de su tiempo, no deja de ser un hombre cuya acción persigue metas diversas. Asimilarlo a una máquina, bajo el pretexto de que asume una labor cuya parte intelectual es reducida, contribuye a hacer crecer aún más su inferioridad. Este prejuicio es aún más indignante en tanto en el estado social actual, la elección de las profesiones no es el resultado de una selección psicológica previa, sino que se encuentra librada al azar de las circunstancias dadas y al desprecio con que W. Taylor considera la mano de obra de sus fábricas y a la hostilidad con la que, en Francia al menos, el sistema ha sido acogido.

Desde el punto de vista sociológico el error es aún más grave. No es posible abstraer al obrero del hombre que forma parte de una actividad social en contextos en los cuales se encuentra más elevado jerárquicamente que en la fábrica. Jefe de familia, asume todas las cargas morales que implican la dirección del hogar y la educación de los niños; ciudadano, se ubica a veces, en la vida política, entre los individuos más activos.

8 ¿No es cometer finalmente un grave error desde el punto de vista profesional desconocer el uso cada vez más difundido de la máquina que, substituyendo al hombre, le impone un trabajo de vigilancia, atención, adaptación rápida y segura para el cual las cualidades mentales son indispensables?

9 Nada en la obra de W. Taylor indica que él se haya posicionado ante los diversos puntos de vista que señalamos. Dejando a otros el cuidado de criticarlo a partir de los datos de la sociología, pensamos que la psico-fisiología tiene el deber, en pro del patrón como del obrero, e incluso de la raza, de señalar el lugar del ser humano en toda organización científica del trabajo.

10 La obra de W. Taylor, a partir del estudio y la crítica que se pueden hacer, nos permitirá fijar los elementos esenciales de la vida obrera y bosquejar las líneas de una organización verdaderamente científica del trabajo humano, oponiéndose a métodos demasiado simplistas. Apoyándonos en los datos de la psico-fisiología, señalaremos la importancia de los problemas de la adaptación obrera, la selección profesional y la fatiga. De este estudio emanará, pensamos, el hecho que patrones y obreros tienen un similar interés en organizar científicamente el trabajo profesional. 